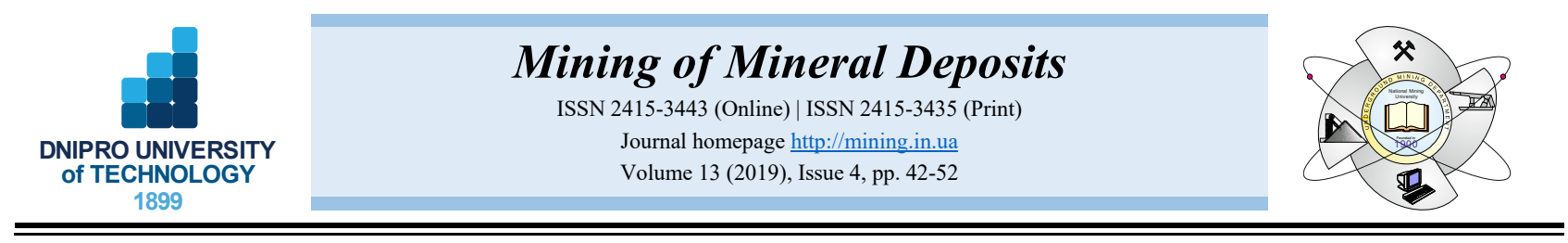

UDC 502.573

https://doi.org/10.33271/mining13.04.042

\title{
DETERMINANTS OF ENVIRONMENTAL DEGRADATION: REFLECTIONS ON THE IMPACT OF IDENTIFIED ECONOMIC VARIABLES ON THE ENVIRONMENT
}

\author{
M. Ramayah ${ }^{1 *}$, R. Rasiah ${ }^{1}$, S. Somasundram ${ }^{1}$, J.J. Turner ${ }^{2}$ \\ ${ }^{\prime}$ Taylor's University, Subang Jaya, Selangor, Malaysia \\ ${ }^{2}$ Asia Pacific University, Kuala Lumpur, Malaysia \\ *Corresponding author: e-mail malarvilly.ramayah@taylors.edu.my, tel.+60356295669
}

\begin{abstract}
Purpose. The main objective of this study is to investigate the determinants of environmental degradation within the broader framework of the environmental Kuznets Curve analysis. To better understand the economic impact on the environment, the study focuses on the relationship between carbon emission and the variables income per capita, trade openness, foreign direct investment, energy use and urbanization.
\end{abstract}

Methods. In the context of the dynamic carbon emission model a Generalized-Method-of-Moments (GMM) technique was used to analyse World Bank of 125 countries for the period 2000 to 2014. This era was chosen as the most appropriate given the completeness of the dataset.

Findings. The findings indicate that economic growth and energy use are significant variables in explaining environmental degradation, supporting previous research in to the particularly negative impact of energy use on the environment. The research however, found that urbanisation had only marginal significance in explaining the impact on the environment.

Originality. The findings contribute to existing research in the area of environmental degradation, providing insight into the debate surrounding urbanisation and $\mathrm{CO}_{2}$ emission which had previously received mixed results. The findings take research forward through the examination of explanatory variables and their respective impact on $\mathrm{CO}_{2}$ emission in countries which have observed an increase in the number of urban dwellers.

Practical implications. Given the debate in academic and practitioner literature around climate change, pollution and a general concern over a lack of collective action to address environmental concerns, the findings have practical implications for government institutions and businesses to better understand the economic impact on the environment.

Keywords: carbon emissions, GDP per capita, foreign direct investment, energy consumption, trade openness, urbanisation, developing countries

\section{INTRODUCTION}

Global warming, the depletion of the ozone, climate change, haze, water pollution, rising sea-level and the continued erosion of coral reefs are just a few of the environmental issues which have been present in media headlines across the globe for the past $10-20$ years. The challenges and concerns surrounding the environment have been widely debated at national and international levels and has resulted in many nations, both individually and collectively, taking a proactive stand against further environmental decline, culminating in the signing of the historic Paris agreement where 195 countries agreed to intensify actions to ensure a sustainable low carbon future by 2030 (UNFCCC, 2015). A report by Climate
Change Tracker highlighted that even if governments managed to fulfill their Paris Agreement pledges, the world is likely to increase in temperature by $3.0^{\circ} \mathrm{C}$ which is twice the assigned $1.5^{\circ} \mathrm{C}$ limit agreed in Paris (Climate Action Tracker, 2018). However, it would appear that this rather gloomy prediction for the future is likely to be further exacerbated given the fact that three years after the Paris agreement, none of the major industrialized countries are on track to fulfill their pledges (Climate Action Tracker, 2018). As a response to the lack of progress towards the Paris agreement, a report by the United Nation has emphasized the dire predicament facing nations, stressing that global emissions have reached historic levels and nations are required to triple their efforts to keep global warming below $2^{\circ} \mathrm{C}$ (UNEP, 2018).

(C) 2019. M. Ramayah, R. Rasiah, S. Somasundram, J.J. Turner. Published by the Dnipro University of Technology on behalf of Mining of Mineral Deposits. This is an Open Access article distributed under the terms of the Creative Commons Attribution License (http://creativecommons.org/licenses/by/4.0/), which permits unrestricted reuse, distribution, and reproduction in any medium, provided the original work is properly cited. 
The urban population is projected to grow by 2030 where urban areas are estimated to house 60 per cent of the global population with one in every three persons living in cities with at least half a million inhabitants (United Nations Department..., 2016). The high projection rate of urbanization is likely to impact the environment especially if cities are not planned and developed adequately. According to a report by UNDESA (2014), unplanned urban expansion can lead to rapid urban sprawl, pollution and negative environmental impact. The adverse impact of urbanization on the environment is especially pronounced in developing countries and compounding the impact on the environment given the fact that urbanization is taking place mainly in developing countries (UNDESA, 2014). Evidence supporting these concerns were highlighted in a report by UN-HABITAT (2012) which underlined environmental concerns in certain developing countries, including, extensive pollution of the Nairobi River in Kenya; ground water pollution, extensive air pollution and traffic congestion in Lahore, Pakistan; poor air quality, depletion of ground water tables and fast receding lakes in Bangalore, India; severe attendant noise pollution and traffic congestion in Beirut, Lebanon (UN-HABITAT, 2012), among others.

Given the acuteness of the environmental problem facing nations, this study is keen to explore the antecedences of environmental degradation and propose effective measures to address what has essentially become a crisis. This study will approach the environmental problem from an economic perspective using the tested environmental Kuznets Curve (EKC) as a theoretical framework. The hypothesis of EKC is that environmental degradation will first increase with income, and later decline as rising income passes beyond a tipping point (Agras \& Chapman, 1999). This conclusion is aligned to the concerns raised with regards developing countries with growing urban population. The developing countries are likely to be high polluters as economic development forces these countries to move to the stage of an industrialised economy (Dinda, 2004). However as these countries progress, economic development changes their status to developed nations, and in alignment with the Kuznets theory, these countries would move to a clean service economy with arguably a better or more positive environmental impact (Dinda, 2004).

The EKC proposition of an inverted U-shape relation between economic growth and economic degradation is well-documented with studies introducing influencers such as trade openness, foreign direct investment and energy use into the model (Harbaugh, Levinson \& Wilson, 2002; Aldy, 2005; Lacheheb, Rahim \& Sirag, 2015). The current study attempts to add value to the existing literature by exploring the impact of urbanization on the environment. In order to determine whether urbanization has an impact on environmental degradation, a scatter plot test is employed to understand whether a correlation exists between these two variables. Figure 1 plots the relationship between urbanization and $\mathrm{CO}_{2}$ emission for high income countries for a duration of 50 years. There is an inverted U-shaped relationship between urbanization and environmental degradation for high income countries.

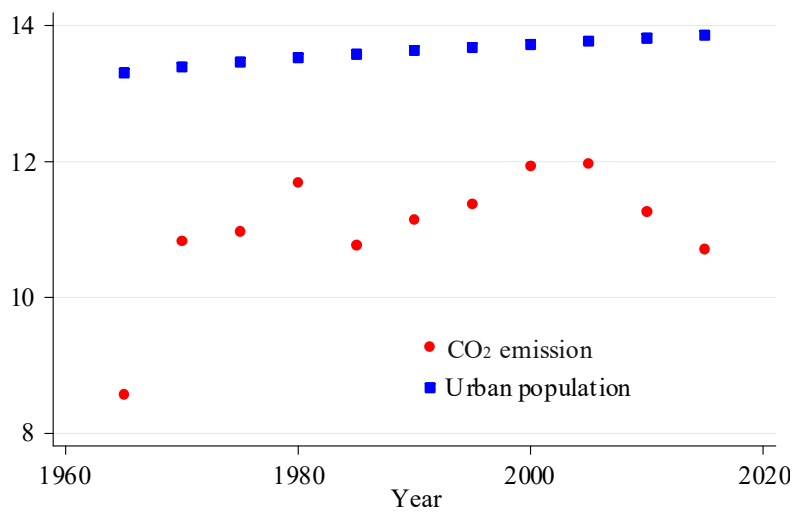

Figure 1. Scatter plot on urbanization and $\mathrm{CO}_{2}$ emission among high income countries, 1960 - 2014. Source: United Nations, Department of Economic and Social Affairs, Population Division (2014). World Urbanization Prospects: The 2014 Revision, CD-ROM Edition; Carbon Dioxide Information Analysis Center, Environmental Sciences Division, Oak Ridge National Laboratory, Tennessee, United States

Figure 2 plots the relationship for low income countries. Interestingly, the scatter plot indicates that urbanization does not impact $\mathrm{CO}_{2}$ emission for low income countries. This preliminary analysis eludes to a potentially interesting relationship between developing countries, urbanization and environmental degradation which will be investigated later in this research.

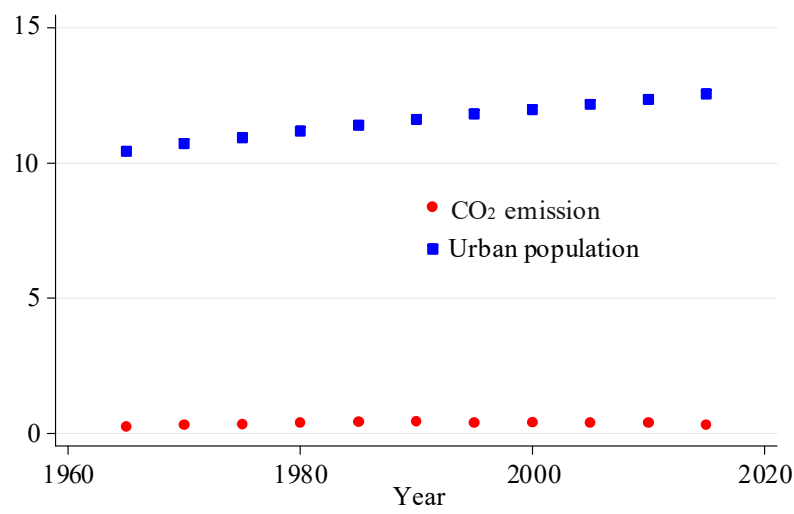

Figure 2. Scatter plot on urbanization and $\mathrm{CO}_{2}$ emission among low income countries, 1960 - 2014. Source: United Nations, Department of Economic and Social Affairs, Population Division (2014). World Urbanization Prospects: The 2014 Revision, CD-ROM Edition; Carbon Dioxide Information Analysis Center, Environmental Sciences Division, Oak Ridge National Laboratory, Tennessee, United States

The aim of this study is to include urbanization in the broader framework of the environmental Kuznets Curve analysis to determine the significance and impact of this variable on environmental degradation. The study plans to employ a dynamic panel analysis which not only consolidates the existing literature, but takes research forward through understanding firstly the role of urbanization in the broader framework of environmental concerns, and secondly proposing appropriate strategies to arrest the further decline of the environment which should prove useful to both academics and practitioners across the globe. 


\section{LITERATURE REVIEW}

A number of academics (Balsalobre-Lorente, Shahbaz, Roubaud, \& Farhani, 2018; Dong, Sun, Jiang, \& Zeng, 2018; Dong, Sun, Li, \& Liao, 2018; Dong et al., 2018; Guan, Wei, Lu, Dai, \& Su, 2018; Månsson, Kibria, Shukur, \& Sjölander, 2018; Zambrano-Monserrate, Silva-Zambrano, Davalos-Penafiel, Zambrano-Monserrate, \& Ruano, 2018; Hussain, Grabara, Razimi, \& Sharif, 2019) support the Environmental Kuznets' Curve theory, which states that as income increases in the initial stages of economic growth, pollution also rises, but after a certain threshold income has been achieved, any further increases in income would see a fall in carbon emissions. In essence, there is an inverted U-shaped relationship between pollution and per capita income. These academics were concentrating on economic growth, trade openness, energy consumption, foreign direct investment and the influence of urbanization on environmenttal degradation specifically $\mathrm{CO}_{2}$ emission. Moreover, previous researchers have employed various methodologies in analyzing Environmental Kuznets' Curve theory. Saboori, Sulaiman, and Mohd (2012) utilised the Auto Regressive Distributed Lag (ARDL) methodology and found that the Environmental Kuznets Curve hypothesis was applicable to the Malaysian setting. Similarly, Tiwari, Shahbaz, \& Hye (2013), in their study on the role of coal consumption in India using the ARDL methodology, support the Environmental Kuznets' Curve findings of previous studies. Rasiah, Guptan, \& Habibullah (2018), applied the dynamic heterogeneous panel estimation techniques of mean group (MG), Pooled MG (PMG) and dynamic fixed effects to analyse a set of macro panel data of the ASEAN-5 countries, to establish the possible causal relations between carbon emissions and its explanatory variables (energy use, trade openness, per capita income and financial development).

Economic growth has been identified as being a crucial determinant of environmental degradation in many of the nations across the globe. Real GDP per capita is the proxy used to represent economic growth. A number of researchers' studies revealed that there exists an inverse U-shaped relationship between $\mathrm{CO}_{2}$ emissions per capita and per capita real GDP. These observations mean that there will be an increase in carbon emission when there is a rise in economic growth but it will eventually decrease after reaching the critical point (Dogan \& Aslan, 2017; Özokcu \& Özdemir, 2017; Shuai et al., 2017; Zhang \& Zhang, 2018). Furthermore, the previous research has indicated that the presence of the EKC hypothesis results in GDP per capita having a positive impact on carbon emission and GDP percapita square has a negative impact on carbon emission (Dogan, Seker, \& Bulbul, 2015; Ali, Abdullah, \& Azam, 2017; Hanif \& Gago-de-Santos, 2017; Lu, 2017; Naradda Gamage, Hewa Kuruppuge, \& Haq, 2017; Nasreen, Anwar, \& Ozturk, 2017; Zoundi, 2017; Balaguer \& Cantavella, 2018; Bello, Solarin, \& Yen, 2018; Dong, Sun, Jiang, \& Zeng, 2018; Dong, Sun, Li, \& Liao, 2018; Dong et al., 2018; Sarkodie \& Strezov, 2018). Only limited research, predominantly the work of Ozturk \& AlMulali (2015) found that income had a negative impact on the $\mathrm{CO}_{2}$ emission and not supporting the Environmental Kuznets' Curve hypothesis.
Trade openness is another important factor which influences $\mathrm{CO}_{2}$ emission. Trade openness is measured by taking the sum of exports and imports of goods and services (constant 2005 US\$) and dividing by GDP (constant 2005 US\$). Trade openness is theoretically said to benefit a country, as specialisation brings about an efficient allocation of scarce resources. Hence, various researchers choose this factor as an explanatory variable when studying the impact on environmental degradation (Ali, Abdullah, \& Azam, 2017; Ali, Ashraf, Bashir, \& Cui, 2017; Alshehry \& Belloumi, 2017; Dogan, Seker, \& Bulbul, 2017; Mrabet \& Alsamara, 2017; Wolde-Rufael \& Idowu, 2017; Zaman \& Moemen, 2017; Balaguer \& Cantavella, 2018; Balsalobre-Lorente, Shahbaz, Roubaud, \& Farhani, 2018; Zhang \& Zhang, 2018). All of these researchers found trade openness to have a positive impact on $\mathrm{CO}_{2}$ emission except for the recent work of Zhang \& Zhang (2018) who reported that the relationship between the two variables was negative.

Other than trade openness, Foreign Direct Investment (FDI) has played an important role in the economic growth of developing nations and as a consequence, arguably influences environmental pollution (Bakhsh, Rose, Ali, Ahmad, \& Shahbaz, 2017; He \& Yao, 2017; Zaman \& Moemen, 2017; Dong et al., 2018; Zhang \& Zhang, 2018). FDI is measured by the inward FDI as a percentage of GDP and can have two possible impacts on the environment, it can either worsen the environment by increasing $\mathrm{CO}_{2}$ emissions or improve the environment by reducing $\mathrm{CO}_{2}$ emissions. From a review of the literature it would appear the former argument carries more weight with many of the previous studies revealing a significantly positive relationship between FDI and $\mathrm{CO}_{2}$ emission. However, some of the earlier studies found that an increase in FDI causes a decrease in $\mathrm{CO}_{2}$ emission. (Pao, Yu, \& Yang, 2011; Atici, 2012; Kivyiro \& Arminen, 2014). Since there is a degree of ambiguity surrounding its impact, it is important to include FDI as an explanatory variable in our study to further understand its role in environmental degradation.

Energy consumption is an inevitable consequence of a country's economic development (Hussain, Salem, Rashid, \& Kamarudin, 2019) and business growth and has been argued to lead to greater $\mathrm{CO}_{2}$ emission, however similarly to the antecedent trade openness, there is a degree of debate surrounding the inevitability of increased energy consumption and greater $\mathrm{CO}_{2}$ emissions particularly in light of the increased use of renewable energy. The variable energy consumption is measured by the $\mathrm{kg}$ of oil equivalent per capita. The majority of the literature has indicated that an increase in energy demand will increase $\mathrm{CO}_{2}$ emission (Ali, Abdullah, \& Azam, 2017; Alshehry \& Belloumi, 2017; He, Xu, Shen, Long, \& Chen, 2017; Moutinho, Varum, \& Madaleno, 2017; Nasreen, Anwar, \& Ozturk, 2017; Özokcu \& Özdemir, 2017; Wang et al., 2017; Wolde-Rufael \& Idowu, 2017; Zaman \& Moemen, 2017; Dong, Sun, Jiang, \& Zeng, 2018; Månsson, Kibria, Shukur, \& Sjölander, 2018). The research of Zambrano-Monserrate, Silva-Zambrano, Davalos-Penafiel, Zambrano-Monserrate, \& Ruano (2018) and Sarkodie \& Strezov (2018) also revealed that an increase in non-renewable energy increases $\mathrm{CO}_{2}$ emis- 
sion however the research also indicated that an increase in renewable energy decreases $\mathrm{CO}_{2}$ emission. The issue of energy consumption and its role in increasing $\mathrm{CO}_{2}$ emissions is further compounded by energy imports which are perhaps unsurprisingly argued to worsen $\mathrm{CO}_{2}$ emissions while energy exports improve environmental quality since major polluting energy sources are exported to other countries (Sarkodie \& Strezov, 2018).

A further antecedent and explanatory variable argued to influence economic degradation and which is the theme underpinning this research is urbanization. A UNDESA (2014) report on World Urbanisation Prospect highlighted that continuing urbanisation and overall growth of the world's population is projected to add 2.5 billion people to the urban population by 2050 . Urbanisation is a process in which a significant portion of the population shift into cities, motivated by the prospect of improved lifestyle, employment prospects and access to amenities which cannot be found in the rural areas. Previous research has used various proxies for urbanization; urbanization growth rate (Azam \& Khan, 2016) and level of urbanization (Abdallh \& Abugamos, 2017; He, Xu, Shen, Long, \& Chen, 2017) and revealed a correlation with $\mathrm{CO}_{2}$ emissions in developing nations. Wang, Zhang, Kubota, Zhu, \& Lu, 2015 highlighted that the carbon emissions tend to increase during the early stages of urbanization; there then comes a point when carbon emissions begin to decrease as urbanization increases. However, there is a degree of debate surrounding the impact urbanization on environmental degradation. Similarly to previously discussed antecedents the current research is divided with a number of studies revealing that urbanization has a significantly negative effect on environment degradation (Azam \& Khan, 2016; Charfeddine \& Mrabet, 2017; Bello, Solarin \& Yen, 2018). While other research revealed that urbanization has a positive impact on $\mathrm{CO}_{2}$ emission (Kang, Zhao, \& Yang, 2016; Abdallh \& Abugamos, 2017; He, Xu, Shen, Long, \& Chen, 2017; Wang et al., 2017; Dai, Liu, \& Wu, 2018; Dong et al., 2018).

This debate surrounding the macroeconomic determinants of environmental degradation underline the need for further research in this area. As the literature related to urbanization and its impact on $\mathrm{CO}_{2}$ emission has revealed mixed results and the tendency for the population particularly in developing countries to move to cities is predicted to increase this research consolidates existing research but also takes research forward by examining those explanatory variables and their respective impact on $\mathrm{CO}_{2}$ emission in countries which has observed an increase in the number of urban dwellers. The research will use the EKC hypothesis to better understand the relationship between specified macroeconomic indicators and environmental degradation.

\section{METHODS}

Within the context of environmental degradation, the study will explore the relationship between carbon emission and macroeconomic variables, specifically income per capita, trade openness, foreign direct investment, energy use and urbanisation, in 125 countries over the period 2000 to 2014 (micro panel data). The data was obtained from the World Development Indicator of World Bank. The summary details of all variables involved in this study are shown in Table 1.

Table 1. Summary details of variables

\begin{tabular}{|c|c|c|c|}
\hline Variable & Descriptor & $\begin{array}{c}\text { Data } \\
\text { source }\end{array}$ & $\begin{array}{c}\text { Expected } \\
\text { sign }\end{array}$ \\
\hline $\begin{array}{l}\text { Carbon } \\
\text { emissions }\end{array}$ & $\begin{array}{l}\mathrm{CO}_{2} \text { emissions } \\
\text { (metric tons } \\
\text { per capita) }\end{array}$ & $\begin{array}{l}\text { WDI, } \\
\text { World } \\
\text { Bank }\end{array}$ & N/A \\
\hline $\begin{array}{l}\text { GDP per } \\
\text { capita }\end{array}$ & $\begin{array}{c}\text { GDP per capita } \\
\text { (constant } 2010 \text { US\$) }\end{array}$ & $\begin{array}{l}\text { WDI, } \\
\text { World } \\
\text { Bank }\end{array}$ & + \\
\hline $\begin{array}{l}\text { Trade } \\
\text { openness }\end{array}$ & $\begin{array}{l}\text { Sum of exports and } \\
\text { imports of goods and } \\
\text { services (constant } \\
2010 \text { US\$)/GDP at } \\
\text { market prices } \\
\text { (constant } 2010 \text { US\$ }\end{array}$ & $\begin{array}{l}\text { WDI, } \\
\text { World } \\
\text { Bank }\end{array}$ & + \\
\hline $\begin{array}{l}\text { Foreign } \\
\text { direct in- } \\
\text { vestment }\end{array}$ & $\begin{array}{c}\text { Foreign direct } \\
\text { investment, net } \\
\text { inflows (\% of GDP) }\end{array}$ & $\begin{array}{l}\text { WDI, } \\
\text { World } \\
\text { Bank }\end{array}$ & + \\
\hline $\begin{array}{l}\text { Energy } \\
\text { consumption }\end{array}$ & $\begin{array}{l}\text { Energy use (kg of } \\
\text { oil equivalent } \\
\text { per capita) }\end{array}$ & $\begin{array}{l}\text { WDI, } \\
\text { World } \\
\text { Bank }\end{array}$ & + \\
\hline Urbanisation & Urban population & $\begin{array}{l}\text { WDI, } \\
\text { World } \\
\text { Bank }\end{array}$ & + \\
\hline
\end{tabular}

The underlying framework of the model specification is based on the studies of Lean \& Smyth (2019), Sebri \& Ben-Salha (2014), Farhani et al. (2014), and Rasiah, Guptan, \& Habibullah (2018). The generalizedmethod-of-moments (GMM) technique (Holtz-Eakin, Newey, \& Rosen 1988; Arellano \& Bond, 1991; Arellano \& Bover, 1995; Blundell \& Bond, 1998) was utilized to analyse the dynamic carbon emission model by using annual data of 125 countries for the 2000 to 2014 period, as this was the only time period where there was complete data for the dependent and independent variables across all 125 countries.

The GMM estimation technique is a dynamic datagenerating process that enables us to investigate how the current dependent variables are influenced by previous ones (Roodman, 2006). The GMM estimation technique is appropriate for this study as it supports micro panel data, and is helpful in cases where the regressors are not strictly exogenous. Aside from that, the GMM estimator provides a solution to the problem of heteroscedasticity and autocorrelation within cross-sections. The datagenerating process of the GMM estimators assumes that the instruments available are based on the lags of the instrumented variables, which are considered "internal" instruments. The GMM estimator is beneficial as it exploits these easily available "internal" instruments that exist within the dataset.

All economic data used in this study were sourced from the World Development Indicators published by the World Bank. The model used in this study was based on Lean \& Smyth (2010), Sebri \& Ben-Salha (2014), Farhani, Chaibi, \& Rault, 2014), and Rasiah, Guptan, \& Habibullah (2018), the empirical long-run relation between carbon emissions, real GDPC, energy use, TO, and FD is written in the following form: and with the GMM procedure, it is estimated the following carbon emissions model equation: 


$$
\begin{aligned}
& \mathrm{LCO}_{2 \mathrm{it}}=\beta_{0 \mathrm{i}}+\beta_{1 \mathrm{i}} \mathrm{LCO}_{2 \mathrm{it}-1}+\beta_{1 \mathrm{i}} \mathrm{LGDPC}_{\mathrm{it}}- \\
& -\beta_{2 \mathrm{i}} \mathrm{LGDPC}_{\mathrm{it}}^{2}+\beta_{3 \mathrm{i}} \mathrm{LTO}_{\mathrm{it}}+\beta_{4 \mathrm{i}} \mathrm{LFDI}_{\mathrm{it}}+ \\
& +\beta_{3 \mathrm{i}} \mathrm{LEU}_{\mathrm{it}}+\beta_{4 \mathrm{i}} \mathrm{LURBAN}_{\mathrm{it}}+\varepsilon_{\mathrm{it}},
\end{aligned}
$$

where:

$\mathrm{CO}_{2}-$ the dependent variable representing carbon emissions;

$\beta_{0 \mathrm{i}}$ - the country-specific intercept, GDPC is the GDP per capita;

TO - trade openness;

FDI - the foreign direct investment;

EU refers to energy consumption;

URBAN refers to the degree of urbanization which is proxied by urban population;

$\varepsilon_{t}-$ the standard error term. The subscripts indicate country $(i)$ and time $(t)$. All variables have undergone logarithmic transformation to linearise the exponential trend of the data used.

\section{RESULTS AND DISCUSSION}

The following analysis and discussion focuses on the long-run relationship between carbon emissions and its determinants, namely GDP per capita, trade openness, foreign direct investment, energy use, and urbanisation. The study used a set of micro panel data of 125 countries for the period 2000 to 2014 (15 years), where the number of cross-section $(N)$ is relatively larger than the time series data $(T)$. The Generalised Methods of Moment (GMM) estimation technique was utilized to analyse the panel data available.

It is worth noting the properties or characteristics of the data used in this empirical analysis, prior to embarking on the estimation of the determinants of carbon emissions. The descriptive or summary statistics of all variables used in this study are shown in Table 2 . The between variance component is found to explain the higher portion of variability in the data. As seen in the case of $\mathrm{CO}_{2}$ emissions, the within variance component only explains $2.72 \%\left(0.165^{2}=0.0272\right)$ of the overall variability in the data. For GDP per capita, the overall variance is $1.470^{2}(=2.1609)$, of which the within variance is $0.150^{2}(=0.0225)$, which indicates that only $2.25 \%$ of the overall variability in the data occurs withincountry. Similarly, for trade openness (TO) the within variance is $0.159^{2}(=0.025281)$, for foreign direct investment (FDI) the within variance is $0.828^{2}(=0.686)$, for energy use (EU) the within variance is $0.171^{2}(=0.0292)$, and for urbanization (URBAN) the within variance is $0.122^{2}(=0.0149)$, suggesting that the between variance component dominates in explaining the variability of the data.

Table 2. Descriptive statistics for key variables of the carbon emission model

\begin{tabular}{lcccccc}
\hline \multicolumn{1}{c}{ Variable } & & Mean & Std. Dev. & Minimum & Maximum & Obs. \\
\hline $\mathrm{LCO}_{2}$ & overall & 1.000932 & 1.147 & -4.058 & 4.206 & 1866 \\
& between & & 1.445 & -3.561 & 3.936 & \\
\multirow{4}{*}{ LGDPC } & within & & 0.165 & 0.266 & 2.047 & \\
& overall & \multirow{2}{*}{8.771} & 1.470 & 5.547 & 11.626 & 1872 \\
& between & & 1.470 & 5.762 & 11.535 & \\
LTO & within & & 0.150 & 7.950 & 9.271 & \\
& overall & \multirow{2}{*}{0.269} & 0.532 & -1.860 & 1.469 & 1813 \\
& between & & 0.504 & -1.616 & 1.304 & \\
LFDI & within & & 0.159 & -1.484 & 0.328 & \\
& overall & \multirow{2}{*}{1.061} & 1.240 & -6.523 & 6.113 & 1784 \\
& between & & 0.946 & -1.801 & 3.795 & \\
LEU & within & & 0.828 & -5.082 & 3.813 & \\
& overall & \multirow{2}{*}{7.499} & 1.546 & 3.161 & 10.911 & 1872 \\
& between & & 1.547 & 3.488 & 10.551 & \\
\multirow{2}{*}{ LURBAN } & within & & 0.171 & 6.385 & 8.557 & \multirow{2}{*}{1872} \\
& overall & \multirow{2}{*}{15.752} & 1.453 & 12.376 & 19.853 & \\
& between & & 1.454 & 12.526 & 19.677 & \\
\hline
\end{tabular}

Aside from describing the basic properties of the data, a graphical representation of the impact of each explanatory variable on carbon emissions is shown in Figure 3. It can be seen that positive relationships exist between carbon emissions and GDP per capita, and carbon emissions and energy use, as shown by the positive slope of the scatter diagrams for the $\mathrm{LGDPC}-\mathrm{LCO}_{2}$ and $\mathrm{LEU}-\mathrm{LCO}_{2}$. Countries with higher levels of GDP per capita and energy use do tend to face higher levels of carbon emissions. However, trade openness, FDI and urbanization do not seem to share a relationship with $\mathrm{CO}_{2}$, as seen in their respective scatter diagrams.

To further confirm the results depicted in Figure 3, the research provides a more meaningful and critical analysis by estimating the relevant GMM estimators in Equation 1.
As the objective of this study is to investigate the determinants of carbon emissions using a set of panel data, this study employed the GMM dynamic panel approach developed by Arellano and Bover (1995) and Blundell \& Bond (1998) through the xtabond 2 user written command (Roodman, 2006) to estimate the carbon emissions model for the 125 countries used in this study.

The results of the one-step and two-step difference GMM and that of the System GMM estimators are reported in Table 3.

The Hansen J-statistic for over-identification and the Difference-Hansen test for erogeneity of instrument subsets are reported. The Arellano-Bond test for zero autocorrelation in first differenced errors is also reported. 
Table 3. Dynamic panel estimation results of the $\mathrm{CO}_{2}$ model using the difference GMM and system GMM estimation methods

\begin{tabular}{|c|c|c|c|c|}
\hline Variables & $\begin{array}{l}\text { GMM 1- } \\
\text { DIF }\end{array}$ & $\begin{array}{l}\text { GMM 2- } \\
\text { DIF }\end{array}$ & $\begin{array}{l}\text { GMM 1- } \\
\text { SYS }\end{array}$ & $\begin{array}{l}\text { GMM 2- } \\
\text { SYS } \\
\end{array}$ \\
\hline \multirow[t]{2}{*}{$\mathrm{LCO}_{2(\mathrm{t}-1)}$} & $0.645^{* * *}$ & $0.603^{* * *}$ & $0.909^{* * *}$ & $0.911^{* * *}$ \\
\hline & (6.04) & $(5.36)$ & (26.18) & (24.49) \\
\hline \multirow[t]{2}{*}{ LGDPC } & $1.072^{* *}$ & $1.213^{* * *}$ & $0.248^{* *}$ & $0.246^{* *}$ \\
\hline & $(2.31)$ & $(2.76)$ & $(2.75)$ & $(2.48)$ \\
\hline \multirow[t]{2}{*}{$\begin{array}{l}\text { LGDPC - } \\
\text { square }\end{array}$} & $-0.0681^{* * *}$ & $-0.0724^{* * *}$ & $-0.0133^{* * *}$ & $-0.0131^{* *}$ \\
\hline & $(-2.65)$ & $(-3.04)$ & $(-2.85)$ & $(2.57)$ \\
\hline \multirow[t]{2}{*}{ LTO } & 0.0126 & 0.0180 & 0.0227 & 0.0194 \\
\hline & $(0.17)$ & $(0.29)$ & $(0.83)$ & $(0.70)$ \\
\hline \multirow[t]{2}{*}{ LFDI } & $0.0192^{* *}$ & 0.0144 & -0.000202 & 0.0000663 \\
\hline & $(2.10)$ & (1.61) & $(-0.04)$ & $(0.01)$ \\
\hline \multirow[t]{2}{*}{ LEU } & $0.379^{* *}$ & $0.393^{* *}$ & 0.0500 & 0.0479 \\
\hline & $(2.28)$ & $(2.51)$ & (1.89) & (1.79) \\
\hline \multirow[t]{2}{*}{ LURBAN } & -0.176 & $-0.252^{* *}$ & 0.00718 & 0.00763 \\
\hline & $(-1.41)$ & $(-2.25)$ & (1.13) & (1.19) \\
\hline $\begin{array}{l}\text { Number of } \\
\text { countries }\end{array}$ & 125 & 125 & 125 & 125 \\
\hline $\begin{array}{l}\text { Number of } \\
\text { observations }\end{array}$ & 1452 & 1452 & 1622 & 1622 \\
\hline $\begin{array}{l}\text { Number of } \\
\text { instruments }\end{array}$ & 92 & 92 & 109 & 109 \\
\hline $\mathrm{m}_{1}$-test & 0.000 & 0.000 & 0.000 & 0.000 \\
\hline $\mathrm{m}_{2}$-test & 0.420 & 0.446 & 0.454 & 0.455 \\
\hline Hansen test & 0.418 & 0.418 & 0.108 & 0.108 \\
\hline $\begin{array}{l}\text { Diff-in- } \\
\text { Hansen }\end{array}$ & 0.757 & 0.757 & 0.915 & 0.915 \\
\hline
\end{tabular}

\section{Notes:}

1. t-statistics are shown in parentheses. ${ }^{*},{ }^{* *},{ }^{* * *}$ denote significance at $10 \%, 5 \%$ and $1 \%$ respectively.

2 . The values reported for $m_{1}$ and $m_{2}$ are the $p$-values for first and second order auto-correlated disturbances.

3. The values reported for Hansen and the DifferenceHansen tests are the p-values.

Table 3 displays empirical evidence to confirm the validity of the instruments employed as the results support the null hypothesis of the over-identifying restrictions being valid. The results also reveal the absence of higher order autocorrelation in the residuals, which complies with the requirements of the GMM theory, allowing the presence of first order serial correlation as shown by the significant $\mathrm{p}$-value for the $\mathrm{m}_{1}$-test, while the results of the $m_{2}$-test reveal the absence of second order autocorrelation. The existence of strictly exogenous instruments is shown by the p-value in the Difference-inHansen test, which supports the null hypothesis of erogeneity of the instrument subsets. We can therefore comfortably indicate that all expected diagnostics have been met.

This study employed four different GMM techniques as shown in columns 1 to 4 of Table 3 , with the purpose of testing the robustness of the carbon emissions model. The overall empirical results demonstrate robustness, as similar results are generated in terms of the magnitude and direction of the coefficients of the explanatory variables using the difference and system GMM estimators.

The results from the GMM estimators reported in Table 3 are based on natural logarithm values of the panel time-series data, the long run coefficient estimates of lagged dependent $\mathrm{CO}^{2}$, GDPC GDPC ${ }^{2}$, TO, FDI, EU and URBAN are econometrically equal to the elasticities of $\mathrm{CO}_{2}$ with respect to real income per capita, the square of real income per capita, trade openness, foreign direct investment, energy use and urbanisation respectively. The results in Table 3 reveal that the reported coefficient estimates are statistically significant for lagged- $\mathrm{CO}_{2}$, real income per capita and real income per capita square for all four GMM estimators, indicating the robustness of the results. Energy use is only found to be statistically significant coefficients when estimated using the one-step and two-step difference GMM, while the coefficients of foreign direct investment and urbanization are only found to be statistically significant when employing one-step difference GMM and two-step difference GMM respectively.

The lagged dependent variable (past year carbon emissions $\left(\mathrm{CO}_{2}\right)$ ) has a positive and significant coefficient across all four estimators, indicating the strong influence that past year carbon emissions has on the current carbon emissions. Similar results were also found in several other studies (Kais \& Sami, 2016; Omri, Nguyen, \& Rault, 2014). With magnitudes of $0.645,0.603$, 0.909 and 0.911 respectively, past year's carbon emissions displays a high degree of consistent impact. Of the coefficients for the explanatory variables comprising of GDP per capita, GDP per capita-square, energy use, trade openness, foreign direct investment and urbanization, GDP per capita, GDP per capita-Square and energy use were significant. Trade openness does not significantly explain carbon emissions across all 4 estimators, whereas foreign direct investment which, is only marginally significant, as shown by the results of the one-step difference-GMM estimator in column 1 of Table 2, but insignificant for others. Urbanisation is only marginally significant in explaining carbon emissions using the twostep difference GMM estimator, but not significant when the other estimators are employed.

The harmful environmental impact of real income per capita is noted in Table 3, as the findings reveal that real per capita GDP or income per capita has a positive relationship with $\mathrm{CO}_{2}$, and these findings are supported with the findings of previous research (Rasiah, Baharom, Ow, \& Habibullah, 2015; Abdallh \& Abugamos, 2017; Hanif \& Gago-de-Santos, 2017; He \& Yao, 2017; He, Xu, Shen, Long, \& Chen, 2017; Li \& Su, 2017; Lu et al., 2017; Mrabet \& Alsamara, 2017; Balsalobre-Lorente, Shahbaz, Roubaud, \& Farhani, 2018; Dong et al., 2018; Guan, Wei, Lu, Dai, \& Su, 2018; Månsson, Kibria, Shukur, \& Sjölander, 2018; Zambrano-Monserrate, Silva-Zambrano, Davalos-Penafiel, Zambrano-Monserrate, \& Ruano, 2018). GDP per capita-Square in contrast, reveals a negative sign which is arguably expected and in line with the Environmental Kuznet Curve theory (EKC) and supported by the findings of previous research (Dogan, Seker, \& Bulbul, 2017; Lu, 2017; Nasreen, Anwar, \& Ozturk, 2017; Zoundi, 2017; Balaguer \& Cantavella, 2018; Bello, Solarin, \& Yen, 2018; Sarkodie \& Strezov, 2018). 
(a)

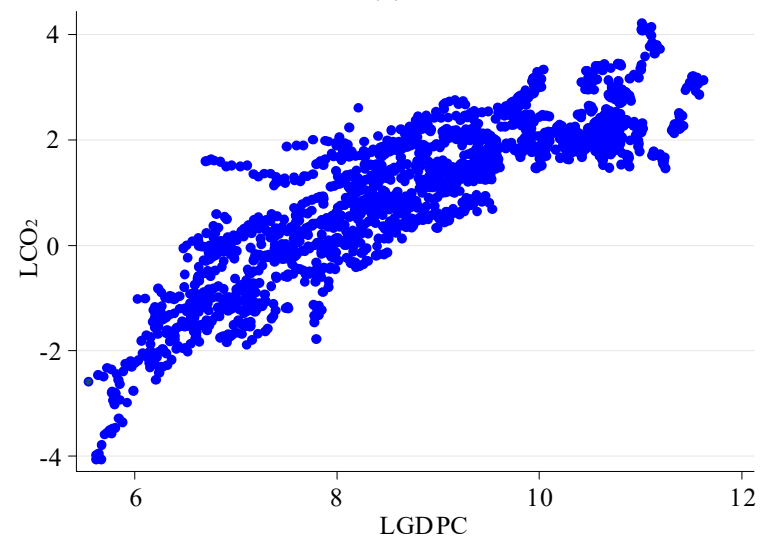

(c)

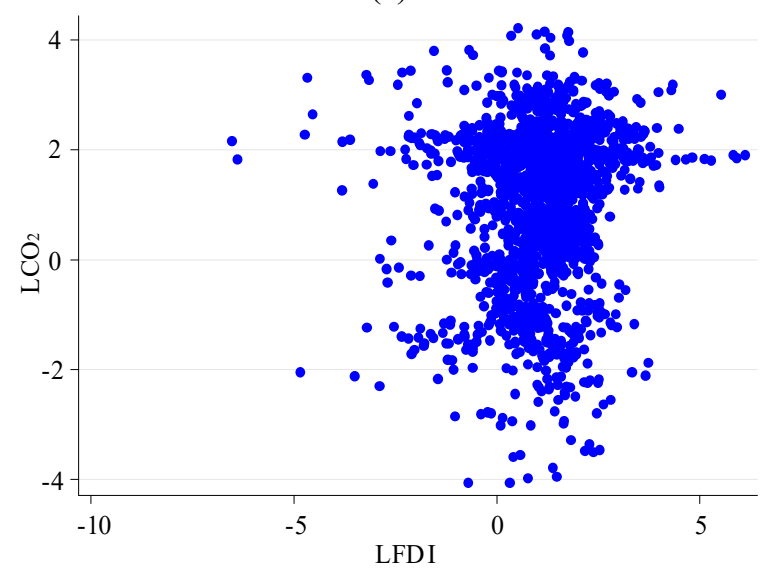

(b)

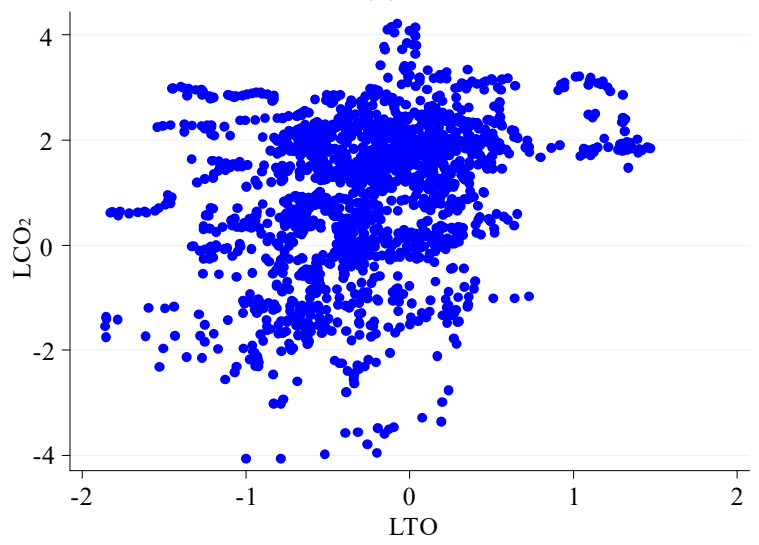

(d)

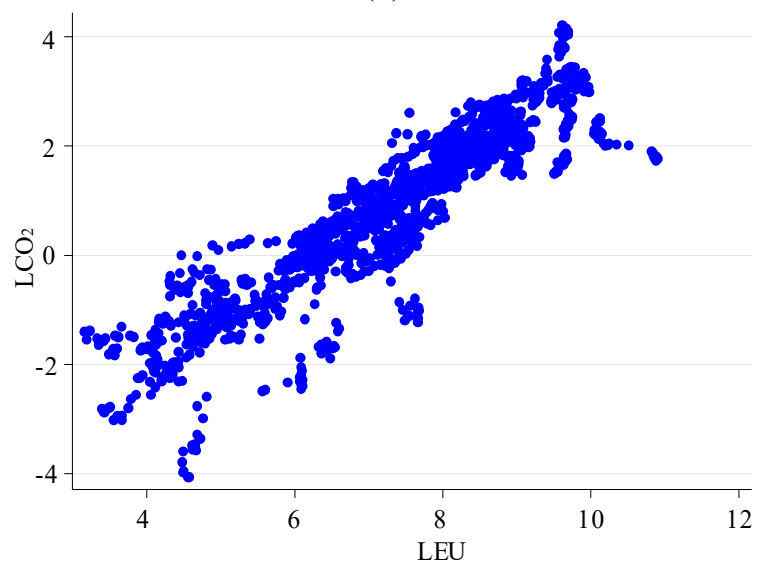

(e)

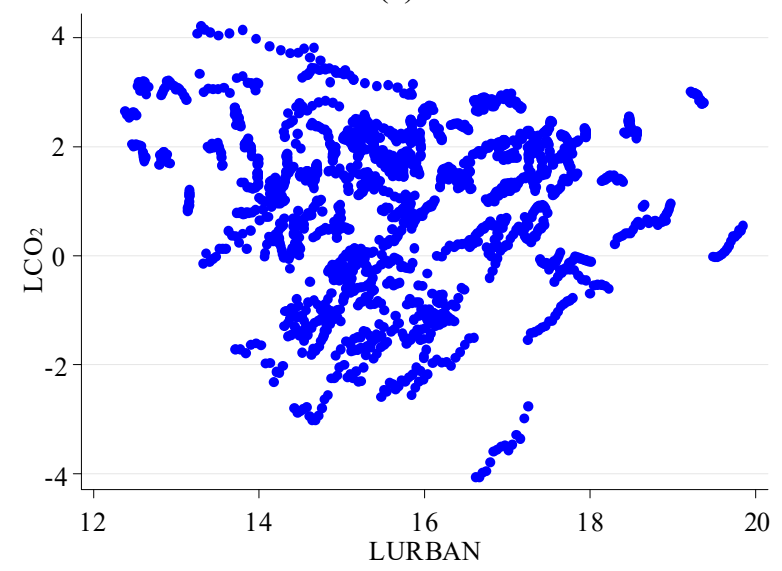

Figure 3. The determinants of carbon emissions - a graphical representation

Energy use is also revealed to cause harmful effects on the environment as it has a positively significant relationship with carbon emissions across all four estimators, which aligns with previous research (Alshehry \& Belloumi, 2017; Ali, Abdullah, \& Azam, 2017; He, Xu, Shen, Long, \& Chen, 2017; Moutinho, Varum, \& Madaleno, 2017; Nasreen, Anwar, \& Ozturk, 2017; Özokcu \& Özdemir, 2017; Wang et al., 2017; Wolde-Rufael \& Idowu, 2017; Zaman \& Moemen, 2017; Dong, Sun, Jiang, \& Zeng, 2018; Månsson, Kibria, Shukur, \& Sjölander, 2018; Zambrano-Monserrate, Silva-Zambrano, DavalosPenafiel, Zambrano-Monserrate, \& Ruano, 2018; Sarkodie \& Strezov, 2018). These results confirm and consolidate existing research, identifying the significance of
GDP per capita and energy use as explanatory variables for environmental degradation but that urbanization was only marginally significant in its impact on the environment. The results confirm the argument that an increase in energy demand will increase $\mathrm{CO} 2$ emission, in the context of renewable energy still being in its relative early stages of use (Alshehry \& Belloumi, 2017; Ali, Abdullah, \& Azam, 2017; He, Xu, Shen, Long, \& Chen, 2017; Moutinho, Varum, \& Madaleno, 2017; Nasreen, Anwar, \& Ozturk, 2017; Özokcu \& Özdemir, 2017; Wang et al., 2017; Wolde-Rufael \& Idowu, 2017; Zaman \& Moemen, 2017; Dong, Sun, Jiang, \& Zeng, 2018; Månsson, Kibria, Shukur, \& Sjölander, 2018). 


\section{CONCLUSIONS}

The main objective of this study was to investigate the determinants of environmental degradation with a focus on urbanisation within the broader framework of the environmental Kuznets Curve analysis. The findings indicate that economic growth, especially different stages of growth significantly impacts environmental degradation. Similarly, energy use is also found to be significant in explaining environmental degradation. The double-edged sword of energy use and economic growth is a well-documented debate with successive governments across the globe seeking a balance between growth and protecting the environment. The findings of the present study support previous research in to the harmful impact of energy use on the environment but did not find urbanization having a significant impact which is perhaps surprising. Urbanisation was measured by urban population with the assumption that a higher concentration of people within a given radius would result in increased congestion and traffic leading to higher $\mathrm{CO}_{2}$ emission. Yet, the findings indicate that urbanisation is only marginally significant in explaining the impact on the environment. Future studies should consider other measures to represent urbanization and possibly consider examining data for major cities instead of countries. Such an approach might provide further insight into the impact of urbanization and the possible variation between cities and regions. Another area for further research is to incorporate a qualitative and quantitative dimension to investigate the perspectives of business leaders and consumers to examine underlying attitudinal issues with regards macroeconomic levers and economic degradation.

The research however is not without its limitations with the data for this study drawn from the period 2000 - 2014. We do not consider this a major limitation, as this period represents a complete data set, representative of 125 countries. That said, in future studies it is perhaps useful to conduct a comparative study of countries in specific regions and, as we will observe in the further recommendations section, a study in cities to gain further insight into the environmental impact of macroeconomic indicators. A further limitation of the study involves the use of panel data which although providing a comprehensive evaluation and comparison of multiple countries was incomplete from 2015 and therefore it is proposed to conduct regional studies using a mixture of quantitative and qualitative research.

\section{ACKNOWLEDGEMENTS}

The authors would like to thank Taylor's University for funding this research project (Source of funding: TRGS (Taylor's Research Grant Scheme); Grant Project Code: TRGS/ERFS/1/2018/TBS/009).

\section{REFERENCES}

Abdallh, A.A., \& Abugamos, H. (2017). A semi-parametric panel data analysis on the urbanisation-carbon emissions nexus for the MENA countries. Renewable and Sustainable Energy Reviews, (78), 1350-1356. https://doi.org/10.1016/j.rser.2017.05.006

Agras, J., \& Chapman, D. (1999). A dynamic approach to the environmental Kuznets Curve hypothesis. Ecological Economics, 28(2), 267-277.

https://doi.org/10.1016/s0921-8009(98)00040-8
Aldy, J.E. (2005). An environmental Kuznets Curve analysis of U.S. state-level carbon dioxide emissions. The Journal of Environment \& Development, 14(1), 48-72. https://doi.org/10.1177/1070496504273514

Ali, G., Ashraf, A., Bashir, M.K., \& Cui, S. (2017). Exploring Environmental Kuznets Curve (EKC) in relation to green revolution: A case study of Pakistan. Environmental Science \& Policy, (77), 166-171. https://doi.org/10.1016/i.envsci.2017.08.019

Ali, W., Abdullah, A., \& Azam, M. (2017). Re-visiting the environmental Kuznets curve hypothesis for Malaysia: Fresh evidence from ARDL bounds testing approach. Renewable and Sustainable Energy Reviews, (77), 990-1000. https://doi.org/10.1016/i.rser.2016.11.236

Alshehry, A.S., \& Belloumi, M. (2017). Study of the environmental Kuznets Curve for transport carbon dioxide emissions in Saudi Arabia. Renewable and Sustainable Energy Reviews, (75), 1339-1347. https://doi.org/10.1016/j.rser.2016.11.122

Arellano, M., \& Bond, S. (1991). Some tests of specification for panel data: Monte Carlo evidence and an application to employment equations. The Review of Economic Studies, $58(2), 277$.

https://doi.org/10.2307/2297968

Arellano, M., \& Bover, O. (1995). Another look at the instrumental variables estimation of errorcomponents models. Journal of Econometrics, (68), 29-51.

Atici, C. (2012). Carbon emissions, trade liberalization, and the Japan - ASEAN interaction: A group-wise examination. Journal of the Japanese and International Economies, 26(1), 167-178. https://doi.org/10.1016/j.jjie.2011.07.006

Azam, M., \& Khan, A.Q. (2016). Testing the environmental Kuznets Curve hypothesis: A comparative empirical study for low, lower middle, upper middle and high income countries. Renewable and Sustainable Energy Reviews, (63), 556-567. https://doi.org/10.1016/j.rser.2016.05.052

Bakhsh, K., Rose, S., Ali, M.F., Ahmad, N., \& Shahbaz, M. (2017). Economic growth, $\mathrm{CO}_{2}$ emissions, renewable waste and FDI relation in Pakistan: New evidences from 3SLS. Journal of Environmental Management, (196), 627-632. https://doi.org/10.1016/i.jenvman.2017.03.029

Balaguer, J., \& Cantavella, M. (2018). The role of education in the Environmental Kuznets Curve. Evidence from Australian data. Energy Economics, (70), 289-296. https://doi.org/10.1016/j.eneco.2018.01.021

Balsalobre-Lorente, D., Shahbaz, M., Roubaud, D., \& Farhani, S. (2018). How economic growth, renewable electricity and natural resources contribute to $\mathrm{CO}_{2}$ emissions? Energy Policy, (113), 356-367. https://doi.org/10.1016/j.enpol.2017.10.050

Bello, M.O., Solarin, S.A., \& Yen, Y.Y. (2018). The impact of electricity consumption on $\mathrm{CO}_{2}$ emission, carbon footprint, water footprint and ecological footprint: The role of hydropower in an emerging economy. Journal of Environmental Management, (219), 218-230. https://doi.org/10.1016/j.jenvman.2018.04.101

Blundell, R., \& Bond, S. (1998). Initial conditions and moment restrictions in dynamic panel data models. Journal of Econometrics, 87(1), 115-143. https://doi.org/10.1016/s0304-4076(98)00009-8

Charfeddine, L., \& Mrabet, Z. (2017). The impact of economic development and social-political factors on ecological footprint: A panel data analysis for 15 MENA countries. Renewable and Sustainable Energy Reviews, (76), 138-154. https://doi.org/10.1016/i.rser.2017.03.031

Climate Action Tracker. (2018). Warming projections global update. Available at: https://climateactiontracker.org/ publications/warming-projections-global-update-dec-2018/ 
Dai, D., Liu, H., \& Wu, J. (2018). Urbanization, energy use, and $\mathrm{CO}_{2}$ emissions: A provincial-level analysis of China. Energy Sources, Part B: Economics, Planning, and Policy, 13(4), 205-210. https://doi.org/10.1080/15567249.2011.637543

Dinda, S. (2004). Environmental Kuznets Curve hypothesis: A survey. Ecological Economics, 49(4), 431-455. https://doi.org/10.1016/j.ecolecon.2004.02.011

Dogan, E., \& Aslan, A. (2017). Exploring the relationship among $\mathrm{CO}_{2}$ emissions, real GDP, energy consumption and tourism in the EU and candidate countries: Evidence from panel models robust to heterogeneity and cross-sectional dependence. Renewable and Sustainable Energy Reviews, (77), 239-245. https://doi.org/10.1016/j.rser.2017.03.111

Dogan, E., Seker, F., \& Bulbul, S. (2015). Investigating the impacts of energy consumption, real GDP, tourism and trade on $\mathrm{CO}_{2}$ emissions by accounting for cross-sectional dependence: A panel study of OECD countries. Current Issues in Tourism, 20(16), 1701-1719. https://doi.org/10.1080/13683500.2015.1119103

Dong, K., Sun, R., Dong, C., Li, H., Zeng, X., \& Ni, G. (2018). Environmental Kuznets Curve for PM2.5 emissions in Beijing, China: What role can natural gas consumption play? Ecological Indicators, (93), 591-601. https://doi.org/10.1016/j.ecolind.2018.05.045

Dong, K., Sun, R., Jiang, H., \& Zeng, X. (2018). $\mathrm{CO}_{2}$ emissions, economic growth, and the environmental Kuznets Curve in China: What roles can nuclear energy and renewable energy play? Journal of Cleaner Production, (196), 51-63. https://doi.org/10.1016/i.jclepro.2018.05.271

Dong, K., Sun, R., Li, H., \& Liao, H. (2018). Does natural gas consumption mitigate $\mathrm{CO}_{2}$ emissions: Testing the environmental Kuznets Curve hypothesis for 14 Asia-Pacific countries. Renewable and Sustainable Energy Reviews, (94), 419-429. https://doi.org/10.1016/j.rser.2018.06.026

Farhani, S., Chaibi, A., \& Rault, C. (2014). $\mathrm{CO}_{2}$ emissions, output, energy consumption, and trade in Tunisia. Economic Modelling, (38), 426-434.

https://doi.org/10.1016/j.econmod.2014.01.025

Guan, X., Wei, H., Lu, S., Dai, Q., \& Su, H. (2018). Assessment on the urbanization strategy in China: Achievements, challenges and reflections. Habitat International, (71), 97-109. https://doi.org/10.1016/j.habitatint.2017.11.009

Hanif, I., \& Gago-de-Santos, P. (2017). The importance of population control and macroeconomic stability to reducing environmental degradation: An empirical test of the environmental Kuznets curve for developing countries. Environmental Development, (23), 1-9. https://doi.org/10.1016/j.envdev.2016.12.003

Harbaugh, W.T., Levinson, A., \& Wilson, D.M. (2002). Reexamining the empirical evidence for an environmental Kuznets Curve. Review of Economics and Statistics, 84(3), 541-551. https://doi.org/10.1162/003465302320259538

He, X., \& Yao, X. (2016). Foreign direct investments and the Environmental Kuznets Curve: New evidence from Chinese Provinces. Emerging Markets Finance and Trade, 53(1), 12-25. https://doi.org/10.1080/1540496x.2016.1138813

$\mathrm{He}, \mathrm{Z}$., Xu, S., Shen, W., Long, R., \& Chen, H. (2017). Impact of urbanization on energy related $\mathrm{CO}_{2}$ emission at different development levels: Regional difference in China based on panel estimation. Journal of Cleaner Production, (140), 1719-1730. https://doi.org/10.1016/j.jclepro.2016.08.155

Holtz-Eakin, D., Newey, W., \& Rosen, H. S. (1988). Estimating Vector Autoregressions with Panel Data. Econometrica, 56(6), 1371. https://doi.org/10.2307/1913103

Hussain, H.I., Grabara, J., Razimi, M.S.A., \& Sharif, S.P. (2019). Sustainability of leverage levels in response to shocks in equity prices: Islamic finance as a socially responsible investment. Sustainability, 11(12), 3260. https://doi.org/10.3390/su11123260
Hussain, H.I., Salem, M.A., Rashid, A.Z.A., \& Kamarudin, F. (2019). Environmental impact of sectoral energy consumption on economic growth in Malaysia: Evidence from ARDL bound testing approach. Ekoloji, 28(107), 199-210.

Kais, S., \& Sami, H. (2016). An econometric study of the impact of economic growth and energy use on carbon emissions: Panel data evidence from fifty eight countries. Renewable and Sustainable Energy Reviews, (59), 1101-1110. https://doi.org/10.1016/j.rser.2016.01.054

Kang, Y.-Q., Zhao, T., \& Yang, Y.-Y. (2016). Environmental Kuznets Curve for $\mathrm{CO}_{2}$ emissions in China: A spatial panel data approach. Ecological Indicators, (63), 231-239. https://doi.org/10.1016/j.ecolind.2015.12.011

Kivyiro, P., \& Arminen, H. (2014). Carbon dioxide emissions, energy consumption, economic growth, and foreign direct investment: Causality analysis for Sub-Saharan Africa. Energy, (74), 595-606. https://doi.org/10.1016/j.energy.2014.07.025

Lacheheb, M., Rahim, A.S.A., \& Sirag, A. (2015) Economic growth and $\mathrm{CO}_{2}$ emissions: Investigating the environmental Kuznets Curve hypothesis in Algeria. International Journal of Energy Economics and Policy, 5(4), 1125-1132.

Lean, H.H., \& Smyth, R. (2010). $\mathrm{CO}_{2}$ emissions, electricity consumption and output in ASEAN. Applied Energy, 87(6), $1858-1864$.

https://doi.org/10.1016/j.apenergy.2010.02.003

Li, R., \& Su, M. (2017). The role of natural gas and renewable energy in curbing carbon emission: Case study of the United States. Sustainability, 9(4), 600. https://doi.org/10.3390/su9040600

Lu, W.-C. (2017). Greenhouse gas emissions, energy consumption and economic growth: A panel cointegration analysis for 16 Asian countries. International Journal of Environmental Research and Public Health, 14(11), 1436. https://doi.org/10.3390/ijerph14111436

Lu, Z.-N., Chen, H., Hao, Y., $\quad$ Wang, J., Song, X., ～\& Mok, T.M. (2017). The dynamic relationship between environmental pollution, economic development and public health: Evidence from China. Journal of Cleaner Production, (166), 134-147.

https://doi.org/10.1016/j.jclepro.2017.08.010

Månsson, K., Kibria, G., Shukur, G., \& Sjölander, P. (2018). On the estimation of the $\mathrm{CO}_{2}$ emission, economic growth and energy consumption nexus using dynamic OLS in the presence of multicollinearity. Sustainability, 10(5), 1315. https://doi.org/10.3390/su10051315

Moutinho, V., Varum, C., \& Madaleno, M. (2017). How economic growth affects emissions? An investigation of the environmental Kuznets Curve in Portuguese and Spanish economic activity sectors. Energy Policy, (106), 326-344. https://doi.org/10.1016/j.enpol.2017.03.069

Mrabet, Z., \& Alsamara, M. (2017). Testing the Kuznets Curve hypothesis for Qatar: A comparison between carbon dioxide and ecological footprint. Renewable and Sustainable Energy Reviews, (70), 1366-1375. https://doi.org/10.1016/j.rser.2016.12.039

Naradda Gamage, S.K., Hewa Kuruppuge, R., \& Haq, I. (2017). Energy consumption, tourism development, and environmental degradation in Sri Lanka. Energy Sources, Part B: Economics, Planning, and Policy, 12(10), 910-916. https://doi.org/10.1080/15567249.2017.1324533

Nasreen, S., Anwar, S., \& Ozturk, I. (2017). Financial stability, energy consumption and environmental quality: Evidence from South Asian economies. Renewable and Sustainable Energy Reviews, (67), 1105-1122. https://doi.org/10.1016/j.rser.2016.09.021

Omri, A., Nguyen, D.K., \& Rault, C. (2014). Causal interactions between $\mathrm{CO}_{2}$ emissions, FDI, and economic growth: Evidence from dynamic simultaneous-equation models. Economic Modelling, (42), 382-389. https://doi.org/10.1016/j.econmod.2014.07.026 
Özokcu, S., \& Özdemir, Ö. (2017). Economic growth, energy, and environmental Kuznets Curve. Renewable and Sustainable Energy Reviews, (72), 639-647. https://doi.org/10.1016/j.rser.2017.01.059

Ozturk, I., \& Al-Mulali, U. (2015). Investigating the validity of the environmental Kuznets Curve hypothesis in Cambodia. Ecological Indicators, (57), 324-330. https://doi.org/10.1016/i.ecolind.2015.05.018

Pao, H.-T., Yu, H.-C., \& Yang, Y.-H. (2011). Modeling the $\mathrm{CO}_{2}$ emissions, energy use, and economic growth in Russia. Energy, 36(8), 5094-5100. https://doi.org/10.1016/j.energy.2011.06.004

Rasiah, R., Baharom, A.H., Ow, C.S., \& Habibullah, M.S. (2015). Time series analysis of the impact of consumption and energy use on environmental degradation: Evidence from Malaysia. Kajian Malaysia, 33(1), 15-32.

Rasiah, R., Guptan, V., \& Habibullah, S. (2018). International journal of energy economics and policy evaluating the impact of financial and economic factors on environmental degradation: A panel estimation study of selected Asian countries. International Journal of Energy Economics and Policy, 8(6), 209-216. https://doi.org/10.32479/ijeep.7111

Roodman, D. (2006). How to do Xtabond2: An introduction to difference and system GMM in Stata. SSRN Electronic Journal, (103), 1-44.

https://doi.org/10.2139/ssrn.982943

Saboori, B., Sulaiman, J., \& Mohd, S. (2012). Economic growth and $\mathrm{CO}_{2}$ emissions in Malaysia: A cointegration analysis of the Environmental Kuznets Curve. Energy Policy, (51), 184-191. https://doi.org/10.1016/j.enpol.2012.08.065

Sarkodie, S.A., \& Strezov, V. (2018). Assessment of contribution of Australia's energy production to $\mathrm{CO}_{2}$ emissions and environmental degradation using statistical dynamic approach. Science of the Total Environment, (639), 888-899. https://doi.org/10.1016/j.scitotenv.2018.05.204

Sebri, M., \& Ben-Salha, O. (2014). On the causal dynamics between economic growth, renewable energy consumption, $\mathrm{CO}_{2}$ emissions and trade openness: Fresh evidence from BRICS countries. Renewable and Sustainable Energy Reviews, (39), 14-23.

https://doi.org/10.1016/j.rser.2014.07.033

Shuai, C., Chen, X., Shen, L., Jiao, L., Wu, Y., \& Tan, Y. (2017). The turning points of carbon Kuznets Curve: Evidences from panel and time-series data of 164 countries. Journal of Cleaner Production, (162), 1031-1047. https://doi.org/10.1016/j.jclepro.2017.06.049

Tiwari, A.K., Shahbaz, M., \& Adnan Hye, Q.M. (2013). The environmental Kuznets Curve and the role of coal consumption in India: Cointegration and causality analysis in an open economy. Renewable and Sustainable Energy Reviews, (18), 519-527.

https://doi.org/10.1016/j.rser.2012.10.031
UNDESA. (2014). World urbanization prospects. Available at: http://esa.un.org/unpd/wup/Highlights/WUP2014-Highlights. pdfdoi:10.4054/DemRes.2005.12.9

UNEP. (2018). The emissions gap report 2018. Available at: http://wedocs.unep.org/bitstream/handle/20.500.11822/26895 EGR2018 FullReport EN.pdf? sequence=1\&isAllowed=y

UNFCCC. (2015). What is the Paris agreement? Available at: https://unfccc.int/process-and-meetings/the-paris-agreement/ what-is-the-paris-agreement

UN-HABITAT. (2012). State of the World's cities 2012/2013: Prosperity of cities. Available at: www.unhabitat.org

United Nations Department of Economic and Social Affairs Population Division. (2016). The World's cities in 2016 data booklet (ST/ESA/ SER.A/392). Available at: http://www.un.org/en/development/desa/population/publica tions/pdf/urbanization/the_worlds_cities_in_2016_data_bo oklet.pdf

Wang, Y., Zhang, C., Lu, A., Li, L., He, Y., ToJo, J., \& Zhu, X. (2017). A disaggregated analysis of the environmental Kuznets Curve for industrial $\mathrm{CO}_{2}$ emissions in China. $\mathrm{Ap}$ plied Energy, (190), 172-180. https://doi.org/10.1016/j.apenergy.2016.12.109

Wang, Y., Zhang, X., Kubota, J., Zhu, X., \& Lu, G. (2015). A semi-parametric panel data analysis on the urbanizationcarbon emissions nexus for OECD countries. Renewable and Sustainable Energy Reviews, (48), 704-709. https://doi.org/10.1016/j.rser.2015.04.046

Wolde-Rufael, Y., \& Idowu, S. (2017). Income distribution and $\mathrm{CO}_{2}$ emission: A comparative analysis for China and India. Renewable and Sustainable Energy Reviews, (74), 1336-1345. https://doi.org/10.1016/j.rser.2016.11.149

Zaman, K., \& Moemen, M.A. (2017). Energy consumption, carbon dioxide emissions and economic development: Evaluating alternative and plausible environmental hypothesis for sustainable growth. Renewable and Sustainable Energy Reviews, (74), 1119-1130. https://doi.org/10.1016/j.rser.2017.02.072

Zambrano-Monserrate, M.A., Silva-Zambrano, C.A., DavalosPenafiel, J.L., Zambrano-Monserrate, A., \& Ruano, M.A. (2018). Testing environmental Kuznets Curve hypothesis in Peru: The role of renewable electricity, petroleum and dry natural gas. Renewable and Sustainable Energy Reviews, (82), 4170-4178. https://doi.org/10.1016/i.rser.2017.11.005

Zhang, Y., \& Zhang, S. (2018). The impacts of GDP, trade structure, exchange rate and FDI inflows on China's carbon emissions. Energy Policy, (120), 347-353. https://doi.org/10.1016/j.enpol.2018.05.056

Zoundi, Z. (2017). $\mathrm{CO}_{2}$ emissions, renewable energy and the Environmental Kuznets Curve, a panel cointegration approach. Renewable and Sustainable Energy Reviews, (72), 1067-1075. https://doi.org/10.1016/j.rser.2016.10.018

\section{ФАКТОРИ, ЩО ВИКЛИКАЮТЬ ДЕГРАДАЦЮЮ НАВКОЛИШНЬОГО СЕРЕДОВИЩА: ВПЛИВ ДЕЯКИХ ЕКОНОМІЧНИХ ПОКАЗНИКІВ НА ЕКОЛОГІЮ}

\section{М. Рамая, Р. Расія, С. Сомасундрам, Дж.Дж. Тернер}

Мета. Визначення факторів, які викликають екологічну деградацію довкілля в широкому контексті екологічної кривої Кузнеця, на основі вивчення взаємозв'язку між вуглецевими викидами і такими змінними як дохід на душу населення, відкритість торгівлі, прямі іноземні інвестиції, використання енергії та урбанізація.

Методика. Для побудови динамічної моделі вуглецевої емісії були використані дані Всесвітнього банку по 125 країнам у період з 2000 по 2014 роки, проаналізовані за допомогою узагальненого методу моментів. Даний проміжок часу був обраний як той, що найбільш повно представляє базу даних.

Результати. Встановлено, що економічне зростання і використання енергії є найсуттєвішими факторами, які визначають екологічну деградацію, що підтверджується більш ранніми дослідженнями негативного впливу використання енергії на навколишне середовище. Виявлено, що урбанізація впливає на стан навколишнього 
середовища тільки побічно. Рекомендовано в наступних дослідженнях розглянути інші заходи для уявлення урбанізації, а саме можливість вивчення даних по великих містах, а не по країнам. Такий підхід може дати додаткове уявлення про вплив урбанізації та можливих відмінностей між містами і регіонами.

Наукова новизна. Отримано нові знання щодо оцінки впливу урбанізації та вуглецевих викидів на навколишнє природне середовище, які раніше мали неоднозначні результати. Прогрес у вивченні даних проблем було досягнуто за рахунок аналізу ключових змінних і їх впливу на емісію $\mathrm{CO}_{2}$ в країнах, де спостерігається зростання міського населення.

Практична значимість. Результати дослідження мають істотне практичне значення для державних установ та бізнесових структур, оскільки допомагають краще зрозуміти сутність економічного впливу на навколишнє середовище і вносять вклад у вирішення проблеми екологічної деградації.

Ключові слова: вуглецеві викиди, ВВП на душу населення, прямі іноземні інвестиціі, споживання енергії, відкритість торгівлі, урбанізація, країни, щзо розвиваються

\section{ФАКТОРЫ, ВЫЗЫВАЮЩИЕ ДЕГРАДАЦИЮ ОКРУЖАЮЩЕЙ СРЕДЫ: ВЛИЯНИЕ НЕКОТОРЫХ ЭКОНОМИЧЕСКИХ ПОКАЗАТЕЛЕЙ НА ЭКОЛОГИЮ}

\section{М. Рамая, Р. Расия, С. Сомасундрам, Дж.Дж. Тернер}

Цель. Определение факторов, вызывающих экологическую деградацию окружающей среды в широком контексте экологической кривой Кузнеца, на основе изучения взаимосвязи между углеродными выбросами и такими переменными как доход на душу населения, открытость торговли, прямые иностранные инвестиции, использование энергии и урбанизация.

Методика. Для построения динамической модели углеродной эмиссии были использованы данные Всемирного банка по 125 странам в период с 2000 по 2014 годы, проанализированные при помощи обобщенного метода моментов. Данный промежуток времени был выбран как наиболее полно представляющий базу данных.

Результаты. Установлено, что экономический рост и использование энергии являются самыми существенными факторами, определяющими экологическую деградацию, что подтверждается более ранними исследованиями негативного влияния использования энергии на окружающую среду. Выявлено, что урбанизация воздействует на состояние окружающей среды только косвенно. Рекомендовано в следующих исследованиях рассмотреть другие меры для представления урбанизации, а именно возможность изучения данных по крупным городам, а не по странам. Такой подход может дать дополнительное представление о влиянии урбанизации и возможных различий между городами и регионами.

Научная новизна. Получены новые знания касательно оценки влияния урбанизации и углеродных выбросов на окружающую природную среду, которые ранее имели неоднозначные результаты. Прогресс в изучении данных проблем был достигнут за счет анализа ключевых переменных и их влияния на эмиссию $\mathrm{CO}_{2}$ в странах, где наблюдается рост городского населения.

Практическая значимость. Результаты исследования имеют существенное практическое значение для государственных учреждений и бизнес структур, поскольку помогают лучше понять сущность экономического воздействия на окружающую среду и вносят вклад в решение проблемы экологической деградации.

Ключевые слова: углеродные выбросы, ВВП на душу населения, прямые иностранные инвестиции, потребление энергии, открытость торговли, урбанизащия, развивающиеся страны

\section{ARTICLE INFO}

Received: 23 July 2019

Accepted: 21 October 2019

Available online: 5 November 2019

\section{ABOUT AUTHORS}

Malarvilly Ramayah, Master of Economics, Senior Lecturer of the School of Accounting and Finance, Taylor's University, 1 Jalan Taylors St, 47500, Subang Jaya, Selangor, Malaysia. E-mail: malarvilly.ramayah@taylors.edu.my

Ratneswary Rasiah, Doctor of Philosophy, Associate Professor of the School of Accounting and Finance, Taylor's University, 1 Jalan Taylors St, 47500, Subang Jaya, Selangor, Malaysia. E-mail: ratneswary.rasiah@taylors.edu.my

Sotheeswari Somasundram, Doctor of Philosophy, Senior Lecturer of the School of Accounting and Finance, Taylor's University, 1 Jalan Taylors St, 47500, Subang Jaya, Selangor, Malaysia. E-mail: sotheeswari.somasundram@,taylors.edu.my

Jason James Turner, Doctor of Philosophy, Head of the Graduate School of Business, Asia Pacific University, 5 Jalan Teknologi St, Taman Teknologi Malaysia, 57000, Kuala Lumpur, Malaysia. E-mail: jasonjamesturner@staffemail.apu.edu.my 